\title{
THE INFLUENCE OF GASTRONOMIC TOURISM TRADITIONAL SUNDANESE FOOD ON TOURIST VISIT DECISSIONS TO BANDUNG
}

\author{
Ayu Nurwitasari \\ Sekolah Tinggi Pariwisata Bandung, \\ Bandung, indonesia \\ ayunurwitasari@yahoo.com
}

\begin{abstract}
Gastronomic Tourism is part of the special interests that explore natural resources and the potential to give rise to the nation's cultural arts and special interest attractiveness as a tourist target . Gastronomic tourism give travelers an authentic culinary education and a much greater understanding and appreciation of the cultural richness and high culinary an area. Bandung has an unique gastronomic traditional Sundanese food with a lively establishment of various types of traditional Sundanese restaurant that not only serves as an element of physiological needs alone but involves elements of culture and the uniqueness of which is the symbol of regionalism. With assets of traditional Sundanese food gastronomic tourism owned by Bandung the government should be able to interpret and packed gastronomic tour as one of the leading tourist attraction that is able to increase tourist visits to Bandung which will directly impact positively on the development. Independent variable in this research is the gastronomic tourism as $(X)$ consisting of (X1) Food as a symbol, (X2) Food as a sign of communion, (X3) Food as a class marker, and (X4) Food as an emblem and the decision to visit as $(Y)$. Object of this study is the opinion of the respondents about the decision gastronomic travelers visiting to Bandung. The method used is descriptive research and verification. Target population in this study were tourists visiting Bandung based on the types of travel in 2013 is equal to 5,179,88. Sample of 100 tourists . In this research systematic sampling. Based on the research that has been done by using descriptive analysis and verification sub-variables that obtain the highest valuation is food as symbol food as a class marker while obtaining the lowest ratings. Sub-variables of the decision to Bandung who obtained the highest valuation is based electoral appeal of Bandung tourism product. While the selection of the number of visits received the lowest ratings. Influence of gastronomic tours with the decision has been a strong relationship. The results showed that the gastronomic tourism significantly influence the decision to choose to visit Bandung as a preferred tourist destination.
\end{abstract}

Keywords: Gastronomics tourism, sundanese cuisine,

\section{Introduction}

Developed into a potential tourism industry can make a major contribution to the movement of a country's economy. Through tourism, the source of state revenue will increase and affect the public welfare. Availability of various modes of transport along with the ease in reaching out to various tourist destinations around the impact on the movement of tourists to various places so as to increase tourist visits to various regions. Tourism is one of the activities that have a strategic role in supporting the development of national economy, is also a sector that can create jobs and stimulate the development of investment. This is also reflected in the tourism sector in Indonesia, which has increased well. Background tourist motivations different impact on the development of a tourist attraction (DTW), which offers a variety of tourist attractions in accordance with the needs of tourists in tourist activity. One of the city located in the west Java city of Bandung which is a favorite destination of choice in the province of West Java. That is because Bandung has many tourist attractions are diverse and is one of the major cities that have a multifunctional role, namely as the administrative capital, the city of trade, industrial city, town education, town tourism, and storefronts of West Java Province . Bandung is one of the tourist destination with a rich culinary offer various types. Sundanese traditional food menu is one of the gastronomic tourism products with a distinct personality, have a cultural identity, as well as a symbol of the area. This is reflected by the establishment of various types of Sundanese restaurant with a variety of concepts, ranging from simple concepts to the kind of classy restaurants . Tourists' interest in visiting the Sundanese traditional restaurants can be observed during the holiday period, almost every traditional Sundanese restaurant packed with traditional Sundanese meal wisatawan. Rumah currently scattered in various areas of the City Bandung. Salah one area that many traditional restaurants sunda stand is the area of Riau street and building a thriving culinary Sate. Wisata not currently 
packaged as a tourist attraction of tourists to be able to increase appreciation of gastronomic tours especially traditional sundanese cuisine . With assets of traditional Sundanese food gastronomic tours owned by the Bandung city government should able to interpret and packed gastronomic tour as one of the leading tourist attraction that is able to increase tourist visits to the city of Bandung which will directly have a positive impact on regional development.

\section{Library Studies}

1. Understanding Tourism Gastronomy

Food is a very important part of the culture of a region. From an economic standpoint, eating is a physiological necessity, where almost 100 $\%$ of travelers spending money for meals where they go for vacation or travel Shenoy 2005 in Yurtseven and Rich ( 2011: 263 ). Gastronomy is expressed also as art or the quest of good eating quality, including in the selection, preparation, service and enjoyment of food and cultural variations or styles of cuisine ( Inskeep , 1991) .

2. Gastronomy Traditional Sundanese

Food culture system includes production, distribution, and consumption of food in which the implied primary fulfillment of human needs, social and cultural as well in order to sustain life and improve the wellbeing of self , family, and community, and are exposed to natural environmental resources ( also social - culture ) that can be exploited . Sabana (2007:2 ). Yuyus ( 2010:20 ) About 80 types of Sundanese Food , more than $60 \%$ made from plants, while the rest is made of fish and meat. So after going through the addition of flavoring derived from plants, the value of organoleptic (taste and aroma) will be more attractive .

3. Understanding Decision Visits

Decision tourists in visiting a tourist destination through the stages in the decisionmaking process for this berkunjung.Dalam been didasri decision-making process by the concept of purchasing decisions in accordance with the stages in the buying process by Oentoro ( 2012:109 ), which consists of six stages, namely:

a. Analyzes your wants and needs

Analysing the desire and the need is demonstrated, especially to determine the wants and needs are not met or satisfied.

\section{b. Assessing sources}

The second stage in the buying process is related to the length of time and the amount of money available to buy.

c. Establish the purpose of purchasing

Stage when consumers decide whether a purchase is made for the purpose, which depends on the type of product and its needs.

$d$. Identify alternative purchases

Stage when consumers began to identify various alternatives purchase.

e. The decision to buy

Stage when consumers make a decision whether to buy or not. If it is considered that the decision is to buy, then the buyer will encounter a series of decisions regarding the type of product, product form , brand, seller, quantity, time of purchase, and how to pay .

\section{$\mathrm{f}$. Behavior after purchase}

The last stage is when the consumer is making a purchase to selected food. Respond from the consumer through the products after purchasing are difference. If the companies want to retain customers, then all complaints from consumers should be accomodate. Fullfill the desires and expectations of consumers can enhance the positive image of the company.

4. Influence the Decision Gastronomic Tourism Visits

Pullphothong and Sopha (2012:3) Gastronomic Tourism became one of the main reasons for the trip. Gastronomic Tourism has a power point related to a variety of products in the sense of authentic multicultural cuisine. A unique culinary destination into a major tourist destination and make traveling tourists will return to the same destination to enjoy a gastronomic tourist each area has a different and unique compared to other destinations.

\section{Methodology}

Based on the variables studied the type of research conducted by the researchers is a descriptive study and verification. The object of research is done in traditional Sundanese restaurant in the area of J1 . Riau and Gedung Sate Bandung region. Data used in this study is primary data is the data of tourist arrivals to the city of London from 2011 to 2013 and secondary data from both internal sources and literature. Techniques of data collection are to use the questionnaire technique, the study of literature, observation and interviews. 


\section{Discussion of Results}

Based on the overall assessment and indicator variables $\mathrm{t}$ gastronomic tours, the responses obtained recapitulation travelers throughout the Figure 1 below:

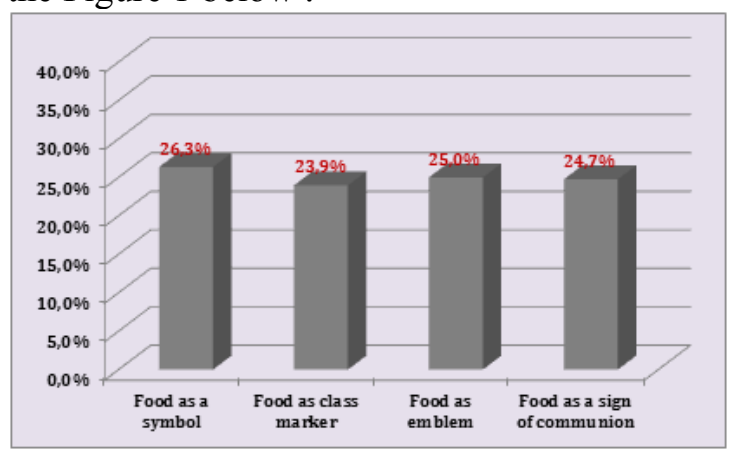

Based on these images is known that the subvariables of gastronomic tours Bandung who obtained the highest valuation is food as a symbol that the percentage recovery of $26.3 \%$. This shows that product as part of a culinary gastronomic tours Bandung has become an important symbol for tourism in the city of Bandung. Typical culinary potential , varied, and interesting in terms of taste, appearance, and how to cook offers a unique experience for tourists in visiting Bandung. Bandung culinary development is inseparable from the active role of government in the city of Bandung and Bandung creative industries creating one organization of UMKM in the culinary business. Active role in the community as well as the creativity of creating diversity, uniqueness, and attractiveness of the dish - Bandung culinary offerings here are increasingly bringing the city of Bandung as gastronomic tourism destination, which in turn typical culinary Bandung became a separate symbol for the city of Bandung .

While the sub-variables of gastronomic tours Bandung who obtained the lowest ratings are food maker as a class, Example, the percentage gain of $23.9 \%$. This shows that the Bandung culinary considered less impact on the division of special classes in the social life of the community. Although the results showed tourists feel quite proud when tasting typical cuisine in Bandung, but because it is basically the traditional food is quite popular in Indonesia Bandung create unique culinary less so can lead to a high sense of pride for tourists, especially domestic tourists in this study.

Based on an overall assessment of the decision variables and indicators visit, the recapitulation of the results obtained throughout the traveler responses presented in Figure 3 below :

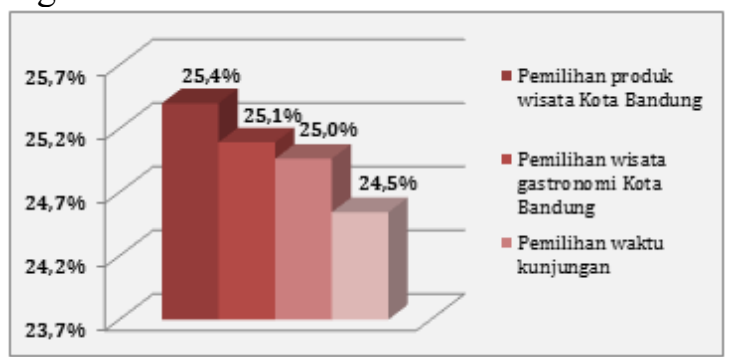

Based on these images is known that the subvariables of the decision to the City of Bandung who obtained the highest valuation is based on the selection of Bandung tourism products, namely the acquisition of a percentage of $25.4 \%$. This shows that the diversity and appeal of Bandung tourism products become the main attraction of tourists want to visit the city of Bandung. As previously explained that the Bandung tourism potential spread of natural attractions, historical, cultural and culinary to shopping. Shopping and culinary tourist favorite, especially the domestic tourists visiting Bandung. Maximizing the potential of tourism to be sustainable tourist attraction may be the government's efforts to develop tourism and increase tourist traffic to the city of Bandung. While the sub-variables of the decision to the City of Bandung who obtained the lowest assessment is the selection of the number of visits, which is the percentage gain of $24.5 \%$. This shows that the number of tourists visiting frequency can have an impact on the desire to make a repeat visit to the city of Bandung. The desire to make a repeat visit is certainly based on the existence of satisfaction during a previous visit or not. Gastronomic Tourism as one of the tourist attraction of Bandung enough to give satisfaction to the tourists so as to make tourists want to come back to the city of Bandung.

Effect of Test Variables Between

a.Coefficient Between Variables large

TABLE 4.16

OUTPUT GASTRONOMIC TOURISM ON TOURIST VISIT DECISSIONS

\begin{tabular}{|l|c|r|r|r|}
\hline Model & R & $\begin{array}{c}\text { R } \\
\text { Square }\end{array}$ & $\begin{array}{c}\text { Adjusted } \\
\text { R Square }\end{array}$ & $\begin{array}{r}\text { Std. Error of } \\
\text { the Estimate }\end{array}$ \\
\hline 1 &, $795^{3}$ &, 632 &, 617 & 2,307 \\
\hline
\end{tabular}
a. Predictors: (Constant), X4, X3, X1, X2
b. Dependent Variable: Y


Based on the results in Table 4:16 above it can be seen that the decision pengaruhwisata gastronomy has been a strong relationship with the correlation coefficient of 0.795 . This shows that when the gastronomic tours able to contribute positively, then the decision to travelers visiting Bandung will tend to be positive or good anyway .

b . Multiple Linear Regression Analysis

TABLE 4:17

TABLE ANOVA ( F TEST ) ANOVAa

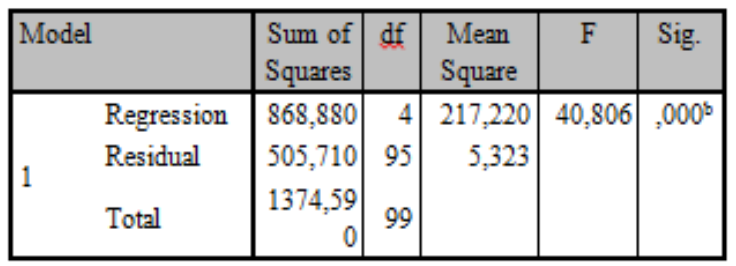

a. Dependent Variable: Y

b. Predictors: (Constant), X4, X3, X1, X2

Based on the above calculation, it is known that the value of $\mathrm{F}$ is equal to 40.806 . To determine the level of significance of the effect of $\mathrm{X}$ on $\mathrm{Y}$ then compared between $\mathrm{F}$ with Ftabel. If the value of $F>F$, it can be concluded Ho is rejected. That is a significant difference between gastronomic tours to travelers visiting decision. From the table above were obtained $\mathrm{F}$ value is 40.806 and is known Ftable of 2.47. While the significance value of 0.000 significance level of $5 \%$, then the regression can be used to predict the decision to visit, or gastronomic tours variables influence the decision of travelers visiting the $95 \%$ confidence level .

\section{TABLE 4:18}

\section{OUTPUT REGRESSION COEFFICIENT}

Coefficientsa

\begin{tabular}{|c|c|c|c|c|c|c|}
\hline \multirow{2}{*}{\multicolumn{2}{|c|}{ Model }} & \multicolumn{2}{|c|}{$\begin{array}{l}\text { Unstandardized } \\
\text { Coefficients }\end{array}$} & \multirow{2}{*}{$\begin{array}{l}\text { Standardized } \\
\text { Coefficients } \\
\text { Beta } \\
\end{array}$} & \multirow[t]{2}{*}{$\mathrm{t}$} & \multirow[t]{2}{*}{ Sig. } \\
\hline & & B & Std. Error & & & \\
\hline \multirow{5}{*}{1} & (Constant & 8,442 & 2,274 & & 3,713 &, 000 \\
\hline & $\mathrm{X} 1$ &, 873 & ,131 &, 441 & 6,667 &, 000 \\
\hline & $\mathrm{x} 2$ & 1,080 & ,193 &, 395 & 5,600 &, 000 \\
\hline & $\mathrm{x} 3$ &, 421 &, 145 & 213 & 2,895 &, 005 \\
\hline & $\mathrm{X} 4$ &, 268 &, 124 &, 136 & 2,169 &, 033 \\
\hline
\end{tabular}

Table 4:18 shows that in partial gastronomic tours consisting of food as a symbol ( $\mathrm{X} 1$ ), food as a class marker ( X2), food as emblem (X3), and food as a sign of communion ( X4 ) influence on the decision to visit tourist ( Y ) . This can be explained in detail as follows : 1 . There is significant influence of the sub variable food as a symbol ( X1) against the decision of visiting tourists with the Sig . $0.000<0.05$. So it can be said that Ho is rejected and Ha accepted .

2 . There is significant influence of the sub variable food as a class marker ( X2) against the decision of visiting tourists with the Sig . $0.000<0.05$. So it can be said that Ho is rejected and Ha accepted.

3 . There is significant influence of the sub variable food as emblem ( X3 ) against the decision of visiting tourists with the Sig . of $0.005<0.05$. So it can be said that Ho is rejected and Ha accepted.

4 . There is a significant relationship between sub-variables of food as a sign of communion ( X2 ) against the decision of visiting tourists with the Sig . amounted to $0.033<0.05$. So it can be said that Ho is rejected and Ha accepted d.coefficient of Determination

To determine the influence of $\mathrm{X}$ on $\mathrm{Y}$, then use the formula coefficient of determination as follows :

$\mathrm{KD}=\mathrm{r} 2 \times 100 \%$

$=(0.795) 2 \times 100 \%$

$=63.2 \%$

The results showed that food as a symbol ( X1 ), food as a class marker ( X2 ), food as emblem (X3), and food as sign of communion ( X4 ) on gastronomic tours ( $\mathrm{X}$ ) jointly influence decisions visiting tourists ( $\mathrm{Y}$ ) amounted to $63.2 \%$. This means that when done well gastronomic tours making Bandung culinary potential not only as a traditional culinary offerings but it can be a cultural identity, a symbol of the peculiarities of the city of Bandung, and is able to provide a sense of pride and traveler broaden the culinary taste, then it will be as well necessarily influence the decision to choose travelers visiting Bandung as their tourism destination choice. While the rest of $36.8 \%$ is influenced by other factors not included in this study.

\section{Conclusion}

Based on the research that has been done by using descriptive analysis and verification between Bandung gastronomic tours and visiting tourists a decision it can be concluded as follows:

1. Tourism gastronomic traditional Sundanese food in Bandung, which includes food as a symbol, as a class marker food, food as emblems, and food as a sign of communion getting good ratings by travelers . The subvariables that obtain the highest valuation is food as symbol food as a class marker while 
obtaining the lowest ratings. This proves that culinary products as part of a gastronomic tour of Bandung has become an important symbol for tourism in the city of Bandung. Typical culinary potential, varied, and interesting in terms of taste, appearance, and how to cook offers a unique experience for tourists in visiting Bandung . Gastronomic Tourism Bandung also assessed have been able to broaden their horizons and although not fully provide a sense of pride for the tourists when tasting the typical culinary Bandung. But with the development of gastronomic tours, culinary peculiarities Bandung became increasingly preserved as cultural assets and heritage that have noble values for the local community.

2. Overall the decision of tourists to visit the city of Bandung, including the high category. Sub-variables of the decision to the City of London who obtained the highest valuation is based electoral appeal of Bandung tourism product. While the selection of the number of visits received the lowest ratings. This shows that the diversity and uniqueness of Bandung tourism products become the main attraction of tourists want to visit the city of Bandung. As previously explained that the Bandung tourism potential spread of natural attractions, historical, cultural and culinary to shopping . Shopping and culinary tourist favorite, especially the domestic tourists visiting Bandung. Maximize the tourism potential especially gastronomic tours to be a tourist attraction that can be sustained government efforts to develop tourism and increase tourist traffic to Bandung

3. Between gastronomic tours with the decision has been a strong relationship. This shows that when properly implemented gastronomic tours, the decision to travelers visiting Bandung will tend to be positive or good anyway. The results also showed that the development of gastronomic tours significantly influence the decision to visit . This shows when done well gastronomic tours making Bandung culinary potential not only as a traditional culinary offerings but can be a cultural identity, a symbol of the peculiarities of the city of Bandung, and is able to provide a sense of pride and traveler broaden the culinary taste, then it is will necessarily influence the decision to choose travelers visiting Bandung as their tourism destination choice.

\section{Recommendations}

In an effort to realize the City of Bandung as a tourist destination gastronomic excellence, the government must continue to improve and develop the potential attractiveness, uniqueness, and diversity of the typical culinary offerings in the city of Bandung in a structured and purposeful. Today, the city of Bandung has become a special tourism icon with culinary products, but impressed that culinary tourism potential is only a mere euphoria without setting or planning contained in the area of tourism planning. Planning and development of gastronomic tours Bandung can be done by empowering local communities to play an active role in the development of culinary tourism. Creative ideas and innovative course will make the community more diverse culinary offering, attractive, and have high competitiveness with other culinary tourist destination. So in the end the government is not only required as a regulator, but also should be a motivator for people to participate and make the City of London as a tourist destination gastronomic excellence.

Resource utilization of local food can be one of the creative media assets to create culinary diversity in Bandung. This potential is very supportive because Bandung is surrounded by areas with rich crops such as Lembang, Ciwidey and areas - other areas which have close accessibility to the city of Bandung.

Understanding and assessment of assets gastronomic aspects of culture, history and identification of opportunities that should be explored in order to affirm and make gastronomic tours have Bandung identity is worth more than just a mere culinary tourism . The role of government, cultural, culinary observers, practitioners and academics are expected to move stimulatory to create gastronomic tours as cultural potential that must be preserved and passed on to the next generation .

Inventory potential gastronomic tours in the city of Bandung at the moment needs to be done to review the gastronomic tourist map as an evaluation and planning direction for the development of gastronomic tours in the future. This needs to be done in order to be well targeted policy development to optimize the potential of existing and planned development that will enrich the gastronomic tours in the city of Bandung. 


\section{Bibliography}

Aaker. 2004. Strategic Marketing Manajemen. New York: John Wiley \& Sons, Inc

Akdon, Ridwan. 2006. Rumus dan Data dalam Aplikasi Statistika. Cetakan I. Bandung : Alfabeta

Ali, Helmi. 2012. Pengembangan Kuliner Aceh Dalam Rangka Memperkaya Atraksi Pariwisata Daerah. http://bkpp.acehprov.go.id/ (Accesed: 4 May 2014)

Alma, Buchari, 2004, Manajemen Pemasaran dan Pemasaran Jasa, Cetakan. Keenam, Alfabeta, Bandung

Alwi Hasan, dkk. 2005. Kamus Besar Bahasa Indonesia. Jakarta : Departemen Pendidikan. Nasional Balai Pustaka

Antonioli Corigliano, R. (2002) "The route to quality: Italian gastronomy networks in operation". In: Hjalager, A. \& Richards, G. (Eds.), Tourism and gastronomy. Routledge, London, pp. 166-185.

Antón Clave, Salvador. Knafou, Rémy . 2012. Gastronomy Tourism and Globalisation.Universitat Rovira i Virgili - Tarra gona, Université Paris 1)

Arikunto, Suharsimi. 2009. Prosedur Penelitian Suatu pendekatan praktek. Jakarta: Rineka Cipta. Asmani

Ariyanto, 2005. Ekonomi Pariwisata. Jakarta

Badan Pusat Statistik Kota Bandung 2013

Brillat-Savarin, J.-A. (1994) The Physiology of Taste, trans: A. Drayton, Harmondsworth: Penguin.

Blakey, Christina. 2012. Consuming Place: Tourismes Gastronomy Connection. Geography 331, Spring 2011, UHH. University of Hawai,,i at Hilo Hawai,i Community College HOHONU 2012 Vol. 10

Dinas Kebudayaan dan Pariwisata Kota Bandung 2009

Espeteix, E. (2007) "Los espacios turísticos del patrimonio alimentario". En Tresserras, J \& Medina, F. (Eds.). Patrimonio gastronómico y turismo cultural en el Mediterráneo. Ibertur, Universitat de Barcelona e Institut Europeu de la Mediterrània. Barcelona, pp. 153-174.

Everett, S. \& Aitchison, C. (2008). The role of food tourism in sustaining regional identity: A case study of Cornwall, South West England. Journal of Sustainable Tourism, 16(2), 150-167. doi: $10.2167 /$ jost 696.0

Gunn, Clare A. 1994. Tourism Planning; Basics, Concept, Cases . Bristol: Taylor \& Francis

Guzmán, Prof. Tomás López. Cañizares, Sandra Sánchez. 2011. Gastronomy, Tourism and Destination Differentiation: A Case Study in Spain Review of Economics \& Finance. ISSNs: 1923-7529; 1923-8401 (C) 2012 Academic Research Centre of Canada

Hendrayana, Made. 2011. Strategi Pengembangan Makanan Tradisional Bali Pada Hotel di Kawasan Sanur. http://www.pps.unud.ac.id/thesis/ (Accesed: 4 May 2014)

Hermawan, Asep. 2005. Penelitian Bisnis: Paradigma Kuantitatif. Jakarta: Penerbit PT. Grasindo

Hjalager, A. \& Richards, G. (Eds.). (2002). Gastronomy and tourism. New York: Routledge.
Hjalager, A \& Antonioli Corigliano, M. (2000) "Food for Tourists - Determinants of an image International Journal of Tourism research. John Wiley \& Sons, Ltd. United Kingdom.

Inskeep, Edward. 1991. Tourism Planning: An Integrated and sustainable Approach. Van Nostrand Reinhold. New York, Inc.

Ismayanti, 2009. Pengantar Pariwisata. Jakarta: Grasindo

Jacinthe Bessière,. 1998. Local Development and Heritage:Traditional Food and Cuisine asTourist Attractions in Rural Areas, Published by Blackwell Publishers, (C) 1998 European Society for Rural Sociology Sociologia Ruralis Volume 38, No. 1, 1998. MA 02148, USA ISSN 0038 0199

Kivela, J., \& Crotts, J. C. (2006). Tourism and Gastronomy: Gastronomy's Influence on How Tourists Experience a Destination. Journal of Hospitality and Tourism Research, 30(3), 354377.

Kotler, Philip and Keller, Kevin Lane. 2009.Manajemen Pemasaran Edisi 12 Jilid 2. Jakarta: PT Indeks

Marketing Management Fourteen Edition. Pearson Education Inc, New Jersey.

Kotler, Philip \& Gary Armstrong, 2008, "Principles of Marketing" Eleventh Edition, Pearson Prentice Hall , New Jersey.

2012. Principles of

Marketing Fourteen Edition. Pearson Education Inc, New Jersey.

Kuncoro, Mudrajad. 2003. Metode Riset untuk Bisnis dan Ekonomi. Jakarta : Erlangga

Londoño, Maria del Pilar Leal. 2012. Gastronomy

Tourism: An Opportunity For Local Development In Catalonia. A Stakeholder Analysis. University of Barcelona . Barcelona Spain

Malhotra, Naresh K. (2005). Riset Pemasaran. (Pendekatan Terapan). Terjemahan Soleh Rusyadi M. Jakarta PT.Indeks Kelompok Gramedia

Mason. 2008. Jurnal Ilmiah Pariwisata. Sekolah Tinggi Pariwisata Bandung

Nazir, Moh. 2007. Metode Penelitian. Jakarta: Ghalia Indonesia.

Nugroho, Ario. 2006. Landasan Program Perencanaan Dan Perancangan Arsitektur Kawasan Wisata Minat Khusus "Watu Tedeng” Di Wonosobo . Universitas Diponegoro

Oentoro SE., MM. Deliyanti. 2012. Manajemen Pemasaran Modern. Yogyakarta: LaskBang PRESSindo

Pullphothong, Ladapha dan Sopha, Chiranut. 2012. Gastronomic Tourism In Ayutthaya, Thailand, Suan Dusit Rajabhat University.

Richards, G. (2002). "Gastronomy: An essential ingredient in tourism production and consumption". En: Hjalager, A., \& Richards, G. (eds.), Tourism and gastronomy. Routledge London, pp. 3-20.

Rustandi, Yuyus. 2010. Seni Dan Budaya Sunda Pusat Studi Hukum Dan Demokrasi. Edisi Pertama, Cetakan ke-1. Perpustakaan Nasional: Katalog 
Dalam Terbitan (KTD). ISBN: 978-602-18266-38

Tjiptono, Fandy. 2008. Strategy Pemasaran Edisi 13.

Yogyakarta: CV. Andi Offset

Turgarini, Dewi. 2013. Inventorikan, lestarikan, manfaatkan dan kembangkan Gastronomi Unggulan Jawa Barat. http://mik.upi.edu/ (Diakses pada 4 Mei 2014)

Sabana, Setiawan. 2007. Nilai Estetis Pada Kemasan Makanan Tradisional Yogyakarta. ITB J. Vis. Art. Vol. 1 D, No. 1, 2007, 10-25

Schiffman, Leon, \& Kanuk, Leslie Lazar. 2000. Consumer Behaviour 7th Edition (Perilaku Konsumen). Jakarta: PT. Indeks

Smith, S. L. J., \& Xiao, H. (2008). "Culinary tourism supply chains: A preliminary examination". Journal of Travel Research, 46(3). SAGE. London. pp. 289-299.

Surakhmad, Winarno. 1982. Pengantar Penelitian Ilmiah, Dasar, Metode, Teknik. Bandung: Transito.

Sugiama. (2008). Metode Riset Bisnis dan Manajemen. Bandung: Guardaya Intimarta

Sugiyono. 2008. Metode Penelitian Kunatitatif Kualitatif dan R\&D. Bandung. Alfabeta.

Sutisna.(2002). Perilaku wisatawan danwisatawan pemasaran dalam perspektif pengaruh perilaku. Jakarta: Erlangga.

Suwantoro, Gamal,SH. 2004. Dasar-Dasar Pariwisata. Yogyakarta: Andi.

Umar, Husein. 2002. Metode riset bisnis. Jakarta: Gramedia Pustaka Utama 2008. Desain Penelitian MSDM dan Perilaku Karyawan. Rajagrafindo

Uma Sekaran, 2006, Research Methods For Business, Edisi 4, Buku 1, Jakarta: Salemba Empat

Triton, P.B. 2005. SPSS 13.0 Riset Statistik Parametrik. Yogyakarta: Penerbit Andi

Wahid Sulaiman, 2004, Analisis Regresi Menggunakan SPSS, Yogyakarta : Andi Offset.

Yurtseven, H. Ridvan and Ozan Kaya, 2011, Tourismos: An International Multidisciplinary Journal Of Tourism Volume 6, Number 2, Autumn 2011, pp. 263-275 UDC: $338.48+640(050)$ Local Food In Local Menus: The Case Of Gokceada 